\title{
Joint Approaches and Best Practices-An Integrated and Coherent EU Arctic Policy in Support of Articles 208 and 214 UNCLOS
}

\author{
HenningJessen

\section{Introduction: A Principle-Fuelled Integrated Arctic Policy of the European Union}

$\mathbf{1}$

Key principles of international environmental law have gradually been integrated into the European Treaties, above all, into the Treaty on the Functioning of the European Union (TFEU) itself. ${ }^{1}$ In order to focus on the Arctic relevance of some EU legal acts, this first section provides a short overview of internationally accepted legal principles of marine environmental law and the applicable EU law, which is generally more progressive in substance as compared to a number of other legal orders.

In a 2016 Joint Communication, the European Commission and the High Representative of the Union for Foreign Affairs and Security Policy reiterated that "the EU is well placed to shape international ocean governance on the basis of its experience in developing sustainable ocean management". This introductory section shall clarify the kind of "experience in developing sustainable ocean management" the Joint Communication refers to. Generally, just like in any other regulatory field, the Eu applies its own unique legal instruments, in particular, secondary legislation imposed on its Members in

* Henning Jessen, Associate Professor for Maritime Law \& Policy, World Maritime University (WMU), Malmö, Sweden.

** This contribution partly draws from the author's article 'The EU's Offshore Oil and Gas Directive (2013/30/EU) and Arctic Governance: Does Regulatory Activity of Third Parties Have Any Impact?' (2016) 2 OGEL (Oil, Gas and Energy Law, Special Issue on Emerging Issues in Polar Energy Law and Governance) <www.ogel.org/article.asp?key=36og> accessed 1 November 2016.

1 Consolidated Version of the Treaty on the Functioning of the European Union (2007) oJ $\mathrm{C}_{306 / 50 .}$

2 Joint Communication to the European Parliament, the Council, the European Economic and Social Committee and the Committee of the Regions: International ocean governance: an agenda for the future of our oceans (2016) Brussels, JoIN (2016) 49 final, 4. 
accordance with Article $288 \mathrm{TFEU}$. This legislation takes the form of legally binding Regulations and more flexible Directives to further the Eu's primary policy objectives. For example, in 2005, as part of the EU's overall "Integrated Maritime Policy", the Commission proposed the adoption of a Directive to implement a broad thematic strategy—the Marine Strategy Framework ${ }^{3}$ to address marine pollution through a long-term programme of diagnosis and action carried out by competent authorities in the Member States and under European regional seas conventions. The continuously evolving EU Arctic policy is a good example for the inclusion of a global environmental policy dimension in EU instruments as advocated since 2008 by the Marine Strategy Framework Directive, which represents the environmental pillar of the Eu's "Integrated Maritime Policy". ${ }^{4}$ While the Directive does not address specifically the environmental impacts of maritime transport, Arctic matters or other uses of the sea, it has served as a catalyst for governance mechanisms, which, over time, generate new EU actions having direct implications for any marine-related sector. As such, it promotes and applies several internationallyaccepted environmental principles, such as:

- the principle of sustainable development, ${ }^{5}$

- the principle of environmental integration,

- the precautionary principle, ${ }^{6}$

3 Directive 2008/56/EC establishing a framework for community action in the field of marine environmental policy, (2008) oJ L164/19; see generally Till Markus/Sabine Schlacke/Nina Maier, 'Legal Implementation of Integrated Ocean Policies: The EU's Marine Strategy Framework Directive', (2011) 26 The International Journal of Marine and Coastal Law, 59-90; Ronán Long, 'The Marine Strategy Framework Directive: A new European approach to the regulation of the marine environment, marine natural resources and marine ecological services', (2011) 29 Journal of Energy and Natural Resources Law, 1-44.

4 See Recital (7) of Directive 2013/30/EU of the European Parliament and of the Council of 12 June 2013 on safety of offshore oil and gas operations and amending Directive 2004/35/EC (2013) OJ L 178/66.

5 See generally Ronán Long, 'Principles and Normative Trends in EU Ocean Governance', in Clive Schofield/Seokwoo Lee/Moon-Sang Kwon (eds), The Limits of Maritime Jurisdiction, Boston/Leiden, Brill Academic Publishers, 2014, 699-726, at 716.

6 The precautionary principle requires States to take measures to protect the environment where there is evidence of serious environmental damage even if scientific certainty is lacking, see Atapattu, Emerging Principles of International Environmental Law, Brill Nijhoff 2007, 204. Historically, the principle is set out in Principle 15 of the 1992 Rio Declaration on Environment and Development, adopted at the UN Conference on Environment and Development, 1992, UN Doc. A/CONF.151/26, (1992) 31 ILM 874 <http://www.un.org/ documents/ga/confi51/aconfi5126-1annexı.htm> accessed 1 November 2016. 
- the polluter pays principle, ${ }^{7}$ and

- the ecosystem approach. ${ }^{8}$

In addition, Article 191(2) TFEU provides that the EU's policy on the environment shall contribute to the pursuit of a number of objectives, including the precautionary principle and the polluter pays principle. ${ }^{9}$ However, Article 191(2) TFEU refers explicitly only to "the regions of the Union". In particular, the first sentence of Article 191(4) TFEU postulates that, "within their respective spheres of competence, the Union and the Member States shall cooperate with third countries and with the competent international organisations". The EU is cautious not to give an outside impression of being a self-appointed global environmental regulator and the direct effect of $\mathrm{EU}$ legal measures is, consequently, generally confined to the EU itself. Nevertheless, explicit intraEU endorsements of principles of international environmental law-as also confirmed on various occasions by the Court of Justice of the European Union $^{10}$ - are of fundamental legal importance. They are especially relevant for the intra-EU persuasiveness of the European Commission's actions in performing its multiple functions of being the guardian of the EU Treaties, the EU's primary executive organ and the most active policy-proposing and agenda-setting EU institution.

Given the transboundary nature of the marine environment and given the original roots of the Eu's emerging Arctic policy, strict territorial and "aquitorial"11 confinement is not particularly helpful in implementation of efficient international environmental rules. This also explains why the EU

$7 \quad$ See, for example, Ling Zhu, 'Is the Polluter Paying for Vessel-Source Pollution?' (2015) Journal of Business Law, 348 .

8 All applicable principles have been discussed in the context of the Eu's Integrated Maritime Policy by Long, n. 4 above 699-726.

9 The provision states that: "Union policy on the environment shall aim at a high level of protection taking into account the diversity of situations in the various regions of the Union. It shall be based on the precautionary principle and on the principles that preventive action should be taken, that environmental damage should as a priority be rectified at source and that the polluter should pay."

10 See, for example, Case 240/83 Procureur de la Republique v ADBHU (1985) ECR 531; Case C-379/92 Re Peralta (1994) ECR I-3453; Case T-13/99 Pfizer v European Commission (2002) ECR II-3305.

11 The term aquitorial relates to the territorial sea as defined in Article 3 (et seq.) of UNCLOS but not, however, to the Exclusive Economic Zone (EEZ) or the Continental Shelf regime as also regulated by UNCLOS. 
evaluated its own Arctic carbon footprint in 2010. ${ }^{12}$ In the wider context, including climate change and the regulation of greenhouse gas emissions (GHG), it has even been argued that if the EU could show that it enforces stricter environmental rules to protect (inter alia) the Arctic environment as compared to the Arctic littoral States, this could also increase the EU's legitimacy and its political influence on Arctic environmental questions. ${ }^{13}$ In any case, such steps confirm the general policy objectives of Article 11 TFEU, which broadly states that, "environmental protection requirements must be integrated into the definition and implementation of the Union's policies and activities, in particular with a view to promoting sustainable development."

In sum, since 2005, the EU has followed a long-term, principle-fuelled and goal-based marine environmental policy. In seeking to achieve "good environmental status" of marine waters by 2020 , the EU is fully aware of the fact that it cannot create legal obligations for third (non-EU) parties. However, both the sustainability approach and the cooperative elements of the EU's marine environmental policy have a global dimension, extending to areas beyond national jurisdiction and thus far beyond the formal territorial and "aquitorial" boundaries of the EU itself to include areas such as the Arctic region. ${ }^{14}$

Arctic Governance and Intensifying Political Efforts of the EU

From a historic viewpoint, it has been argued that the EU's initial interest in developing its own Arctic Policy has been largely motivated by geopolitical considerations, in particular by Russia planting its flag on the sea bottom beneath the North Pole on 1 August 2007..$^{15}$ It is true that this unilateral symbolic act (also largely geared towards the global media and allegedly privately sponsored) coincides with the EU beginnings to evaluate its own political stance in the Arctic more systematically since 2007-2008. However, it also

12 'EU Arctic footprint and policy assessment: Final report' (2010, Berlin, Ecologic Institute); see also Kristine Offerdal, 'The EU in the Arctic' (2011) International Journal 861, 872.

13 See Offerdal, n. 12 above, at 872.

14 Although associated with the EU Member State Denmark, it must be stressed that (since 1 February 1985) Greenland is not part of the EU (then EEC) territory anymore, following the results of a referendum of 1982 . Rather it is included in the list of overseas countries and territories set out in Annex II to the TFEU. In accordance with Article 198 TFEU, the purpose of the association of the overseas countries and territories with the $\mathrm{EU}$ is to promote the economic and social development of the overseas countries and territories and to establish close economic relations between them and the $\mathrm{EU}$ as a whole.

15 See Offerdal, n. 12, 863. 
overlaps with the EU highlighting its own responsibilities in global environmental matters and specifying its own Integrated Maritime Policy in more detail, for example, by passing the Marine Strategy Framework Directive, as discussed above. In fact, the reasons for the EU Commission to deploy more manpower on Arctic issues since 2007/2008 are multi-layered and composed of a number of different political motivations. ${ }^{16}$ At the forefront of those EU motives are issues commonly associated with the buzzword sustainable development, in particular relating to global climate change, as well as other environmental concerns.

The emerging EU Arctic policy itself is made up of a continuously evolving network of "soft law" instruments: ${ }^{17}$ The Foreign Affairs Council passed Council conclusions in 2009, ${ }^{18}$ in $2014^{19}$ and in $2016 .{ }^{20}$ Generally, EU Council conclusions are non-binding political instruments. However, a series of official Council conclusions will often pave the way for future legally-binding intra-EU instruments. If the Commission can refer to a series of "bottom up" Council conclusions the desire to enter into a new "hardened" phase of Eu policy integration gets more and more persuasive. Remarkably, the title of the Arcticrelated conclusions developed from merely addressing an incoherent variety of "Arctic Issues" in 2009 to a more institutionalized "Developing a European Union Policy towards the Arctic Region" in 2014. This may reflect a gradual formulation of a policy on Arctic issues to address EU interests and responsibilities. In particular, paragraph 6 of the 2014 Council conclusions recognised "the efforts of the Arctic states to develop joint approaches and best practice to address the potential environmental impact and safety concerns related to increasing activities in the region" calling for a strengthened collaboration of the EU and its agencies with Arctic Council bodies in addressing "common Arctic

16 See Offerdal, n. 12, 861-877, who does not deny the EU's multi-purpose approach to the Arctic and specifically stresses the changing role of Norway in first motivating the EU in a proactive way (to discover the Arctic at all as a dormant policy area) while later having to slow down the Commission and taking a more defensive approach.

17 All EU instruments discussed below are available online at <http://ec.europa.eu/ maritimeaffairs/policy/sea_basins/arctic_ocean/index_en.htm $>$ accessed 1 November 2016.

18 Council of the European Union, Council conclusions on Arctic issues (2009) 2985th Foreign Affairs Council, Brussels. On the substance of these Council conclusions see Offerdal, n. 12, 871 .

19 Council of the European Union, Council conclusions on developing a European Union Policy towards the Arctic Region (2014) Foreign Affairs Council, Brussels.

20 Council of the European Union, Council conclusions on the Arctic (2016) (Foreign Affairs Council meeting, Brussels). 
challenges". However, in 2016, the coordinated position of the Commission and the EU Member States was reduced in ambition and substance. These conclusions merely reiterated issues raised and addressed by the preceding Council conclusions.

2012 and 2016 witnessed the publications of two more, ambitious, Joint Communications by the European Commission and the High Representative of the EU for Foreign Affairs and Security. ${ }^{21}$ In contrast to EU Council conclusions, a Joint Communication (and also a Communication issued solely by the Commission) does not reflect a coordinated approach between the EU Commission, other participating EU institutions and the EU Member States. Rather, a Communication represents a vision of its originator(s) setting out the details for the most important cornerstones of a certain EU policy area. It has been rightly pointed out that sometimes such documents are mistaken for representing official positions of the $\mathrm{EU}$ as a whole. ${ }^{22}$ However, this is not the case and this is also a reason why Communications can be far more extensive and detailed in nature as compared to Council conclusions.

The 2012 Arctic Joint Communication was built on a broader 2008 joint paper (from the same originators) on climate change and international security ${ }^{23}$ and on an earlier 2008 Commission Communication on "the EU and the Arctic Region". ${ }^{24}$ The 2012 Joint Communication included a total of 28 action points adopting the strapline of "knowledge, responsibility, engagement". ${ }^{25}$ In particular, the 2012 Arctic Joint Communication stressed the considerable financial engagement and contribution of the EU to Arctic research and the EU's support for a sustainable use and management of Arctic resources. The document avoided addressing politically contentious issues (such as the earlier idea of creating a new Arctic Treaty System). The 2016 Joint Communication builds on its 2012 predecessor, stressing that the Eu's primary objective is an "integrated" policy for the Arctic, which also

21 Joint Communication to the European Parliament and the Council: Developing a European Union Policy towards the Arctic Region: progress since 2008 and next steps (2012) Brussels, JOIN (2012) 19 final; Joint Communication to the European Parliament and the Council: An integrated European Union policy for the Arctic (2016) Brussels, JoIN (2016) 21 final.

22 See Offerdal, n. 12, 862.

23 Climate change and international security, Paper from the High Representative and the European Commission to the European Council (2008) S113/o8.

24 Communication from the Commission to the European Parliament and the Council: The European Union and the Arctic Region (2008) Brussels, сом (2008) 763 final.

25 See Jason Chuah, 'The Development of an EU Arctic Policy? Perhaps Not ...' (2012) 18 Journal of International Maritime Law, 251-252. 
ensures effective synergies between the various EU funding instruments in the Arctic region. That is also why "knowledge, responsibility, engagement" are still the three cornerstones of an integrated EU Arctic Policy which will highlight, in the future, three key further policy objectives of the $\mathrm{EU}$ to

- protect and preserve the Arctic environment in cooperation with the people who live there, and in particular relating to climate change,

- promote sustainable use of resources in and around the Arctic, and

- foster international cooperation on Arctic issues, emphasizing enhanced scientific cooperation. ${ }^{26}$

Finally, the European Parliament passed relevant (non-binding) Resolutions, in particular, an Arctic-specific Resolution of $2014^{27}$ which is based on a broader Resolution of 2011 on a sustainable EU policy for the High North. ${ }^{28}$ In sum, the continuously intensified effort of the EU to establish a fully-fledged Arctic strategy has not yet led to any Eu hard law (in the form of Directives or even directly binding Regulations). Rather, the evolving EU policy highlights, more and more, the necessity of integrating different policy aspects, such as scientific research, climate mitigation and adaptation strategies or sustainable innovation and investment, in a more coherent way. This political process is characterized by a visible shift from an initial EU approach, which was more focussed on geopolitics, to a more innovation-centred and research-related attitude. For example, the EU has devoted financial resources to create and develop Arctic observatory networks, and to facilitate access to research facilities in the Arctic to scientists from Europe and beyond. This is done by funding projects such as INTERACT, a multi-disciplinary network of 58 land-based Arctic and northern research stations, building capacity throughout the Arctic for environmental monitoring, research, education and outreach. ${ }^{29}$ The EU is also initiating a new five-year project (2016-2021) coordinated by Norway to develop an Integrated Arctic Observing System (INTAROS) ${ }^{30}$ and two new

26 Joint Communication to the European Parliament and the Council: An integrated European Union policy for the Arctic, Brussels (2016), JoIN (2016) 21 final, 4.

27 European Parliament Resolution of 12 March 2014 on the EU strategy for the Arctic (2013/2595 (RSP)).

28 European Parliament resolution of 20 January 2011 on a sustainable EU policy for the High North $(2009 / 2214$ (INI)).

29 <http://www.eu-interact.org/> accessed 1 November 2016.

30 The Intaros project will involve scientists in 14 European countries as well as in a number of countries elsewhere in the world and has a $€_{15.5}$ million budget. 
projects to understand the impact of the changing Arctic on the weather and climate of the Northern Hemisphere. The projects APPLICATE (Advanced Prediction in Polar Regions and Beyond: Modelling, Observing System Design and Linkages Associated with a Changing Arctic Climate) (2016-2020, €8 million budget) and Blue-Action (2016-2021, $€ 7.5$ million budget) will involve scientists in 13 European countries as well as in a number of countries elsewhere in the world. ${ }^{31}$

All in all, the evolving integrated EU Arctic policy addresses the whole spectrum of practical measures to promote the sustainable use of Arctic resources. A reply given by the High Representative of the EU for Foreign Affairs and Security on behalf of the Commission to a question of a Member of the European Parliament can serve as a "diplomatic showcase" for the state of EU affairs in Arctic matters. In 2014, the parliamentarian simply asked (inter alia): "Does the EU have specific interests in the Arctic region?"32 The written reply of the High Representative explicitly referred to the 2012 Arctic Joint Communication and to the other EU soft law instruments. It stressed that the EU would be stepping up its engagement with its partners, under the Joint Communication's notion of "knowledge, responsibility, engagement", to jointly meet the challenge of safeguarding the environment while ensuring the sustainable and peaceful development of the Arctic region, in particular through investment in knowledge, promoting responsible approaches to arising commercial opportunities and constructive engagement with Arctic partners.

The question then becomes: Where should the EU pursue these policies? With which partners should it cooperate? The obvious location would appear to be with the Arctic Council. From a global perspective, the Arctic Council is the key international policy coordination forum in Arctic matters. ${ }^{33}$ Recent discussions about its continuous enlargement in relation to its governmental,

31 <https://www.whitehouse.gov/the-press-office/2016/og/28/fact-sheet-united-stateshosts-first-ever-arctic-science-ministerial > accessed 1 November 2016.

32 See: Answer given by High Representative/Vice-President Ashton on behalf of the Commission, 24 June 2014 "Question for written answer E-002847/14 to the Commission", S.P.F. Silvestris (PPE), "Subject: The race for the Arctic: European prospects" (11 March 2014), OJ 2014/C 326/o1 (written questions by Members of the European Parliament and their answers given by a European Union institution).

33 See generally on the Arctic Council, for example, Betsy Baker, 'Offshore Oil and Gas Development in the Arctic: What the Arctic Council and International Law Canand Cannot-Do', (2013) AsIL Proceedings, 275-279; Lilly Weidemann, International Governance of the Arctic Marine Environment (Springer International Publishing, 2014), 49; Svein Vigeland Rottem, 'A Note on the Arctic Council Agreements', (2015) 46 Ocean Development \& International Law, 50-59; Olav Schram Stokke, 'International institutions 
intergovernmental and non-governmental "non-Arctic" recurring observers demonstrate the political willingness of various third-party stakeholders to participate more actively in emerging Arctic governance. ${ }^{34}$ Quite naturally, this political process of continuous "procedural enlargement" includes the EU, which has - on various occasions - already been an ad hoc observer to Arctic Council meetings. Although it is not yet among the list of accepted recurring ("non ad hoc") observers to the Arctic Council-in contrast to more than 30 other stakeholders - this is likely to be only a temporary, diplomatic side note. ${ }^{35}$ Despite this, it appears prudent for the EU to look for alternative routes to influence the development of policies relating to the Arctic. In the following sections, the Eu's regulation of Arctic offshore operations is discussed as an example of how its regulation can — at least potentially — generate both internal and external policy ramifications in a particular regulatory area with or without cooperation with the Arctic Council.

\section{A Regulatory Example: The Eu's Offshore Directive and its "Arctic Relevance"}

By 2011, the European Commission had warned that the likelihood of a major offshore accident in European waters remained "unacceptably high" referring to 14 past major accidents - globally—in offshore oil and gas operations since the 1980s (for example, well blow-outs and total loss of production platforms).${ }^{36}$ In response to the "wake up call" of the 2010 "Deepwater Horizon" disaster ${ }^{37}$ and-less prominently, also as a reaction to the 2009 Montara oil

and Arctic governance', in Olav Schram Stokke, Geir Hønneland (eds), International Cooperation and Arctic Governance (Routledge, 2007), 164-184.

34 As of 2016, there were twelve non-Arctic States, nine Intergovernmental and InterParliamentary Organizations and eleven Non-governmental organizations (NGOs) with recurring observer status in the Arctic Council. It can be expected that this list is will be extended in the years to come.

35 The Arctic Council received the application of the Eu for observer status affirmatively, but deferred a final decision on implementation until the Council Ministers agree by consensus, with the understanding that the EU may observe Council proceedings until such time as the Council acts on the application, see "Roadmaps for international cooperation", Commission Staff Working Document (2014) Brussels, SwD (2014) 276 final, at 15.

36 See European Commission Press Release (2011) IP/11/126o, 1.

37 See generally: Melissa K. Merry, Framing Environmental Disaster-Environmental Advocacy and the Deepwater Horizon Oil Spill, (Routledge, 2014), 77; Sergei Vinogradov, 
spill ${ }^{38}$ — the Commission prepared legislative action in this policy area. One of the reasons for this initiative was also the fact that-since "Deepwater Horizon" - the tolerance of the general public for environmental damage had reached an all-time low. ${ }^{39}$ The intra-EU conciliation efforts finally resulted in Directive 2013/30/EU.

Directive 2013/30/EU on safety of offshore oil and gas operations, entered into force on 18 July 2013 and rests on the broad foundation of Article 191 TFEU. ${ }^{40}$ It is explicitly based on the EU's long-term sustainability objectives, as stressed by the Marine Strategy Framework Directive. ${ }^{41}$ In particular, it aims to address "the cumulative impacts from all activities on the marine environment", and seeks to establish "the linking of particular concerns from each economic sector with the general aim of ensuring a comprehensive understanding of the oceans, seas and coastal areas, with the objective of developing a coherent approach to the seas taking into account all economic, environmental and social aspects (...)".42

The Directive is a complex legal act of 44 Articles and nine Annexes. Highlighting first some of the general administrative requirements, the act mandates the Eu Member States to introduce or update legal rules on different levels such as:

'The Impact of the Deepwater Horizon: The Evolving International Legal Regime for Offshore Accidental Pollution Prevention, Preparedness, and Response' (2013) 44 Ocean Development \& International Law, 335-362; Greg Gordon, 'The Deepwater Horizon Disaster: the Regulatory Response in the United Kingdom and Europe', in Richard Caddell/Rhidian Thomas (eds), Shipping, Law and the Marine Environment in the 21st Century: Emerging Challenges for the Law of the Sea-Legal Implications and Liabilities (Lawtext Publishing Ltd., 2013), 181-210.

38 See Stephen Tromans, 'Pollution from Offshore Rigs and Installations' in Bariş Soyer and Andrew Tettenborn (eds), Offshore Contracts and Liabilities (Informa Law, 2014), 253, 257.

39 See Interview with Eero Ailio, Deputy Head of Unit Retail Markets, Coal and Oil at the European Commission: <http://www.dnv.com/industry/oil_gas/publications/updates/ Oil_and_Gas_Update/2013/02_2013/Preventing_major_offshore_accidents_in_Europe .asp $>$ accessed 1 November 2016.

40 See Recital (1) of Directive 2013/30/EU, n. 4.

41 See Recital (6) of Directive 2013/30/EU, n. 4, stating that “(...) By reducing the risk of pollution of offshore waters, this Directive should therefore contribute to ensuring the protection of the marine environment and in particular to achieving or maintaining good environmental status by 2020 at the latest, an objective set out (by the Marine Strategy Framework Directive)".

See Recital (7) of Directive 2013/30/EU, n. 4. 
- independence and objectivity of the competent authority within each EU Member State ensuring it has adequate human and financial resources;

- efficient and early public participation in decisions regarding potential offshore oil and gas exploration operations on the environment;

- participation of the employees in matters affecting safety and human health at work; 43

- warranties and continued verifications of comprehensive concepts on environmental management and of preventing major accidents by operators/ owners, ${ }^{44}$

- updated documentary obligations of the owners/operators to be verified by the competent authority;

- the formulation and continuous improvement of norms and strategies to prevent major accidents, in particular, analysis of causes of accidents;

- the introduction of coordinated internal and external emergency response plans and transboundary cooperation;

- international exchange of information and public transparency.

According to Recital (17) of the Directive, "within the (EU), there are already examples of good standards in national regulatory practices relating to offshore oil and gas operations. However, these are inconsistently applied throughout the (EU) and no Member State has yet incorporated all of the best regulatory practices in its legislation for preventing major accidents or limiting the consequences for human life and health, and for the environment." Consequently, the Directive seeks to introduce and to serve as a catalyst for implementing those best regulatory practices, necessary to deliver effective regulation, which secures the highest safety standards and protects the environment. Thus, the Directive supports the view that internationally-accepted standards are needed to help ensure safe, environmentally responsible, and effective oil and gas operations since these help establish performance requirements and to mainstream best practices. ${ }^{45}$

43 See Gordon, n. 37 above, at 207.

44 The term "operator" is legally defined in Article 2(5) of the Directive as "the entity appointed by the licensee or licensing authority to conduct offshore oil and gas operations, including planning and executing a well operation or managing and controlling the functions of a production installation". The term "owner" is legally defined in Article $2(27)$ of the Directive as meaning "an entity legally entitled to control the operation of a non-production installation."

45 See Stephen Green, Paul Steenhof and Brian Walsh, 'Development of Operational Standards for Arctic Oil and Gas Operations' (2014) Oceans-St. John's, 1, 3 (DOI: 10.1109/ OCEANS.2014.7003107). 
Moreover, the Directive has also introduced a legal obligation of regulatory cooperation and it includes some provisions on offshore oil and gas operations outside of the EU. This is particularly important in the context of this paper because the Directive also has some "Arctic Relevance". The act is inter alia intended to serve as a future "diplomatic tool" for the EU to further promote the highest standards of offshore safety globally, sharing best practices and improving standards in cooperation with third countries, with a particular emphasis on sensitive sea areas, such as the Arctic. In this context, Recital (52) and Article 33(3) of the Directive addresses matters of possible significance for Arctic governance.

On the policy level, Recital (52) of the Directive classifies the Arctic waters as "a neighbouring marine environment of particular importance for the EU" which plays an important role in mitigating climate change. As a result, the serious environmental concerns relating to the Arctic waters would require "special attention to ensure the environmental protection of the Arctic in relation to any offshore oil and gas operation, including exploration, taking into account the risk of major accidents and the need for effective response". After that, Recital (52) specifically addresses Denmark, Finland and Sweden as concomitant EU/Arctic Council Member States, encouraging them in particular "to actively promote the highest standards with regard to environmental safety in this vulnerable and unique ecosystem, such as through the creation of international instruments on prevention, preparedness and response to Arctic marine oil pollution, and through building, inter alia, on the work of the Task Force established by the Arctic Council and the existing Arctic Council Offshore Oil and Gas Guidelines." ${ }^{\text {46 }}$

On the material level of legal obligations, Article 33 of the Directive introduces three sub-provisions on a "coordinated approach towards the safety of offshore oil and gas operations at the international level". The provision specifically authorizes the European Commission

1. to promote cooperation with third countries that undertake offshore oil and gas operations in the same marine regions as Member States,

2. to facilitate the exchange of information between Member States with offshore oil and gas operations and adjacent third countries with similar operations in order to promote preventive measures and regional emergency response plans, and

46 The 2009 guidelines are available online <http://www.pame.is/index.php/projects/ offshore-oil-and-gas $>$ accessed 1 November 2016. 
3. to promote high safety standards for offshore oil and gas operations at the international level in relevant global and regional fora, including those relating to Arctic waters.

Although, only Article 33(1) of the Directive includes explicit references to internal "close cooperation" of the Commission with the Eu Members "without prejudice to relevant international agreements", it is clear that intensified intra-EU cooperation and observance of the relevant international agreements by the European Commission is anticipated throughout the Directive. For example, EU Directive 2013/30/EU refers eleven times to "best practices and standards". Thus, the act acknowledges that the safety of offshore oil and gas operations is governed by a set of rules which are often drafted and substantiated by private business actors and which regularly follow a performancebased approach rather than being based on more inflexible (governmentally imposed) prescriptive requirements. ${ }^{47} \mathrm{~A}$ good example of relevant standards is found in the work of the International Standardization Organization (ISO). One of its specialized committees, Committee ISO/TC 67 on Materials, Equipment and Offshore Structures for Petroleum, Petrochemical and Natural Gas Industries, has already developed close to 200 globally applicable business standards for the offshore oil and gas industry. In 2012, a new Sub-Committee on Arctic Operations (ISO TC 67/SC8) was formed. It followed up with "ISO 19906:2010" which had successfully established Arctic design standards for material, equipment, and offshore structures. Iso TC $67 / \mathrm{SC} 8$ has established seven further expert working groups on the technical working level to address questions going beyond the design of offshore structures. ${ }^{48}$ The aim of the ISO TC $67 / \mathrm{SC} 8$ is nothing less than the "standardization of operations associated with exploration, production and processing of hydrocarbons in onshore and offshore Arctic regions, and other locations characterized by low ambient temperatures and the presence of ice, snow, and/or permafrost". As a result, completely new standards for offshore oil and gas operations in cold climate

47 This topic is also discussed by Myron H. Nordquist and Aimee Fausser, 'Offshore Drilling in the Outer Continental Shelf: International Best Practices and Safety Standards in the Wake of the Deepwater Horizon Explosion and Oil Spill', in Michael W. Lodge and Myron H. Nordquist (eds), Peaceful Order in the World's Oceans (Brill Academic Publishers, 2014), $115^{-145}$.

Green, Steenhof \& Walsh, n. 45 above. 
regions are being developed, thus potentially closing a gap in the international standards landscape. ${ }^{49}$

Nevertheless, a remaining weakness is that there is insufficient coordination of existing best practices and standards across institutions. This results in a patchwork of rules. The Arctic Council's guidelines, for example, are based on the same environmental principles and concepts and could possibly be integrated with the works of the Iso, ${ }^{50}$ but this is yet to happen. For example, the approach of the Protection of the Arctic Marine Environment Working Group $(\mathrm{PAME})^{51}$ aims to improve the safety culture in the oil and gas industry where a huge gap between theory and practice still exists. ${ }^{52}$ The PAME working group on Arctic Oil and Gas Safety Management meets twice a year to assess the progress made and to develop its work plans. Its 2009 Arctic Offshore Oil and Gas Guidelines stressed in particular that: "Good and transparent governance, comprehensive but responsive regulatory regimes, and the use of international standards and practices coupled with evolving advances in technology and best practices have lessened the effects of oil and gas activities over time, including those in the offshore. But risks may arise as conditions change or new areas are explored and developed and evidence also shows that accidents will happen and best practices will not always be followed. Governments should continue to ensure that best practices, including oil spill response mechanisms, are in place before activities begin." 53

Moreover, the Working Group's 2014 Report on “Systems Safety Management and Safety Culture" included a whole section on regulatory regimes and standards, stressing, in particular, Arctic standards and best practices. ${ }^{54}$ This report has also identified nine key Arctic safety elements and applies those safety elements in relation to the regulatory requirements for Norway, Canada,

49 See $<$ http://www.iso.org/iso/home/store/catalogue_tc/catalogue_tc_browse.htm?commid= $652790>$ accessed 1 November 2016.

5o On the application of general environmental principles by the Arctic Council see Baker, n. 33 above, at 276 .

51 See <http://www.pame.is/> accessed 1 November 2016.

52 Lloyd's List of 29 September 2015, 'Safety issue under-reporting 'endemic', offshore report finds'.

53 Available online at <http://www.pame.is/index.php/projects/offshore-oil-and-gas> accessed 1 November 2016, at p. 8.

54 At 11-14, available online at <http://www.pame.is/index.php/projects/offshore-oil-andgas/systems-safety-management-and-safety-culture> accessed 1 November 2016. 
Greenland and the United States. ${ }^{55}$ Notably, Russia is missing in this comparative analysis as conducted by the Arctic Council working group. Thus, the regulatory picture is still not complete. However, in contrast to the Arctic Council working group, Russia is actively present at the Iso and has even taken on a leading role in the follow-up to the "Barents 2020" project which was initially (from 2007) a bilateral Russian-Norwegian project with the aim of assessing the standards needed for safeguarding people, environment and asset values in the Barents Sea. 56

There is, therefore, potential for more institutionalized ways of cooperation to agree on international standards to be developed and for better coordination of those standards. There are examples of how such cooperation and coordination may work. For example, the European Committee for Standardization (CEN) has cooperated generally with the Iso under the framework of the Vienna Agreement since 1991. ${ }^{57}$ The Vienna Agreement provides a framework for continuous technical cooperation between CEN and ISO, including regular exchanges of information, mutual representation at meetings, and a parallel adoption of standards at European and international levels. The existing cooperation between CEN and ISO has yet to be translated to the Arctic context in the future. In sum, there is scope and potential to bring some of these regulations together in a more coherent way.

In any case, the finalization of the work of ISO TC $67 / \mathrm{SC} 8$ will contribute to ensuring safer and more effective Arctic oil and gas operations while also ensuring the protection of the environment and the people working and living in the region. Probably, the biggest advantage of successfully drafting Iso standards for Arctic offshore oil and gas operations is the fact that it would be possible to reference those standards in future regulations or guidelines by Arctic Council Members. Other national States and also the CEN (under the framework of the 1991 Vienna Convention) as well as EU secondary legislation could follow and a good start has been achieved by Directive 2013/30/EU. ${ }^{58}$ The EU could therefore continue with this route to influence offshore installations

55 Ibid., Appendix A-Table A (Summary Table of Selected Safety Management Systems Regulatory Requirements for Norway, Canada, Greenland and the United States).

56 Barents 2020 Final Report 2009, Assessment of international standards for safe exploration, production and transportation of oil and gas in the Barents Sea Harmonisation of Health, Safety, and Environmental Protection Standards for the Barents Sea, <http:// www.dnvusa.com/Binaries/Barents_2020_report_\%2ophase_3_tcm153-519577.pdf> accessed 1 November 2016.

57 The text of the Vienna Agreement is available at <http://www.cencenelec.eu/intcoop/ StandardizationOrg/Pages/default.aspx > accessed 1 November 2016.

Green, Steenhof and Walsh, n. 45 above, at 6. 
activities in the Arctic. Indeed this route-involving indirect cooperation with the Arctic Council could prove more beneficial than attempting direct.

Alternative routes include influencing actions by EU national companies in the Arctic and influencing the development of legislation in other States. The first of these is provided for in the EU's Offshore Directive discussed above. The directive has established a stringent and complex safety regime to bring the risk of EU-related offshore accidents down to an absolute minimum. It sets out clear-but nevertheless lengthy - rules covering the whole lifecycle of all exploration and production operations from initial design to the final abandonment or decommissioning of platforms and rigs. The EU recognizes that "it may not be possible to enforce application of the corporate major accident prevention policy outside of the EU" (see Recital (38) of the Offshore Directive). However, as a result of Article 19(8) of the Directive, the EU Members will nevertheless ensure that operators and owners also have to include their offshore oil and gas operations outside of EU marine waters in their corporate major accident prevention policy documents. This is a commendable step, as "backing out" for purely geographic reasons will not be tolerated by the European regulators at the national level. At some point of time, this provision might even apply to Arctic offshore operations of EU oil majors such as the Italian Eni SpA which began pumping in late 2015 at the Goliat oil field, an offshore oil field in the Norwegian sector of the Barents Sea.

The second can be seen in a recent study focussing on some identified weaknesses of the Brazilian offshore oil and gas safety regime specifically took the UK, Norway and the United States as possible legal role models for a future reform of the applicable domestic Brazilian rules. ${ }^{59}$ Remarkably, in 2015, the United States published proposed rules on exploratory drilling on the us. Arctic Outer Continental Shelf, which also added to an emerging patchwork of best practices of national regulators in this sensitive area ${ }^{60}$ Just like the applicable European regime(s) the us legislative proposal implemented a mixture of performance-based and prescriptive safety standards. Of course, the draft

59 See Pietro A.S. Mendes, Jeremy Hall, Stelvia Matos and Bruno Silvestre, 'Reforming Brazil's Offshore Oil and Gas Safety Regulatory Framework: Lessons from Norway, the United Kingdom and the United States' (2014) 74 Energy Policy, 443-453; see also a description of a recent fatal offshore oil and gas accident in Brazilian waters: "Explosion Kills At Least 3 at Petrobras Oil Platform", <http://www.maritime-executive.com/article/explosion-killsat-least-3-at-petrobras-oil-platform > accessed 1 November 2016.

6o See: Us Department of the Interior, Bureau of Safety and Environmental Enforcement, 30 CFR Parts 250 and 254, Bureau of Ocean Energy Management, 30 CFR Part 550, (2015) 'Oil and Gas and Sulphur Operations on the Outer Continental Shelf-Requirements for Exploratory Drilling on the Arctic Outer Continental Shelf; Proposed Rule', Federal Register, vol. 80, No. 36, Part III. 
law made no explicit references to the law of foreign nations. Nevertheless, it could be tentatively inferred from recent literature that other national regimes had not been completely disregarded in the informal consultative process. ${ }^{61}$ Additionally, the proposed rules addressed specifically some "multilateralized" guidelines of the Arctic Council on Outer Continental Shelf oil and gas operations. ${ }^{62}$

The combined and coordinated rule standardization driven by multiple and largely different stakeholders including, inter alia,

- the eight Arctic Council Members,

- the (currently) 32 recurring observers of the Arctic Council,

- the EU as a unique legal entity,

- the International Standardization Organisation (ISO), possibly in cooperation with the European Committee for Standardization (CEN)

- certain national regulators combined, such as the EUOAG ${ }^{63}$ the NSOAF $^{64}$ or the $\mathrm{IRF}^{65}$ and,

- industry associations, such as the International Oil and Gas Producers Association (OGP $)^{66}$

should lead to a "race to the top" of international best practices and safety standards. This has already occurred, for example, as a result of implementing

61 See, for example, Betsy Baker and Roman Sidortsov, 'The Legal and Regulatory Regime for Offshore Hydrocarbon Resources in the U.S. Arctic' (2014) <http://www.americanbar.org/ groups/environment_energy_resources/resources/energy_law_us_russia.html> accessed 1 November 2016, see especially the concluding sentence of the paper: "Taking a critical and open look at how other Arctic countries address similar issues can help the United States improve its own laws and regulations and to take a leadership role in setting regionappropriate standards for operations in the Arctic offshore."

62 For example, the 2009 Arctic Offshore Oil and Gas Guidelines of the Arctic Council and the 2014 Arctic Council Offshore Oil and Gas Guidelines on Systems Safety Management and Safety Culture.

63 The EUOAG was established in 2012 with Commission Decision C 18/17 (2012) OJ C 18/8. It is formed by Member States' authorities covering both offshore safety and related marine environmental protection, <http://euoag.jrc.ec.europa.eu/> accessed 1 November 2016.

$64<$ <ttp://www.psa.no/nsoaf/category999.html> accessed 1 November 2016.

$65<$ http://www.irfoffshoresafety.com/> accessed 1 November 2016.

$66<$ http://www.iogp.org/Safety> accessed 1 November 2016. 
strict private vetting standards in the oil tanker industry. A real challenge, however, will be a more efficient and visible coordination of this multidimensional race in implementation of Article 208 UnCLOS ("Pollution from seabed activities subject to national jurisdiction") as well as Article 214 ("Enforcement with respect to pollution from seabed activities"). This will be a difficult task. Nevertheless, the fourth and fifth paragraph of Article 208 UnClos request the Members (including the $\mathrm{EU}$ ) to "endeavour to harmonize their policies in this connection at the appropriate regional level" and "to establish global and regional rules, standards and recommended practices and procedures to prevent, reduce and control pollution of the marine environment (...)".

In academic literature, progressive calls have even been made suggesting a new UNCLOS implementation agreement relating to Article 208 and for international standards for offshore drilling. ${ }^{67}$ This is currently, however, far from practical reality. For example, there is still no "Arctic Offshore Regulators Forum" on the horizon (as proposed by the PAME working group in 2014). However, the ultimate advantages of such a forum and enhanced international standardization are quite clear. For example, gaps in the international standards landscape could be closed more efficiently. Second, more possibilities would be created to reference emerging or accepted international standards in national laws. This also includes easier methodology for updates via the built-in change process applicable to the international standards themselves. Finally, performance-based approaches could emanate even further as being more safety-efficient in comparison to more prescriptive, governmentallyimposed laws.

Mindful of the already existing multi-stakeholder coordination fora, it would nevertheless be a good development if UNCLOS Member States would recall that Articles 208, 214 UNCLOS do actually exist and that the provisions require a higher degree of harmonization and defragmentation in the 21st century. A comprehensively standardized regulation of the offshore oil and gas industry operating in the Arctic and in other recognized particularly sensitive sea areas will be able to avoid the application of "sub-standards" in the absence of efficient enforcement by national (flag) States (a problem known in the shipping industry for some time).$^{68}$ On the contrary, intensified coordination of international and national standards and enhanced international cooperation could lead to better chances of higher safety standards and more efficient mitigation of remaining environmental risks.

67 See Nordquist and Fausser, n. 47 above, at 143.

68 See generally Jörn-Ahrend Witt, Obligations and Control of Flag States (Lit Verlag 2007), 274 . 